\title{
Modelling variability of within-ring density components in Quercus petraea Liebl. with mixed-effect models and simulating the influence of contrasting silvicultures on wood density
}

\author{
Édith Guilley ${ }^{\mathrm{a}^{*} 1}$, Jean-Christophe Hervéb, Françoise Huber ${ }^{\mathrm{a}}$, Gérard Nepveu ${ }^{\mathrm{a}}$ \\ “Équipe de recherches sur la qualité des bois, Centre Inra de Nancy, 54280 Champenoux, France \\ ${ }^{b}$ Équipe de dynamique des systèmes forestiers, Engref, Centre de Nancy, 14, rue Girardet, 54042 Nancy cedex, France
}

(Received 16 March 1998; accepted 3 February 1999)

\begin{abstract}
Ring average density, earlywood and latewood widths and densities were measured through microdensitometry on radial strips. The strips were sawn in two radii sampled at various heights from 82 oaks (Quercus petraea Liebl.) split into stands and regions (24 200 available rings). Mixed models were constructed with age from the pith and ring width as quantitative effects to determine which factors influence wood density components, either region, stand, tree or position in commercial logs. The contribution to the total variability of each tested factor was then assessed. The next step consisted in evaluating the ring average density model established at breast height on a new sampling method. The ring average density model was finally used to simulate the influence of contrasting silvicultures on wood density, the simulation including the between-tree variability for both density and radial growth. (C) Inra/Elsevier, Paris.)
\end{abstract}

$\mathrm{X}$-ray densitometry / sessile oak / mixed model / simulation

Résumé - Modélisation de la variabilité des composantes intra-cerne de la densité du bois chez Quercus petraea Liebl. à l'aide de modèles à effets mixtes et simulation des effets de sylvicultures contrastées sur la densité du bois. La densité moyenne, les largeurs et densités du bois initial et final ont été mesurées par microdensitométrie sur des barrettes de bois. Les barrettes ont été prélevées sur deux rayons et échantillonnées à plusieurs hauteurs sur 82 arbres répartis en parcelles et régions (24 200 cernes mesurés). Des modèles à effets mixtes sont construits avec l'âge depuis la moelle et la largeur de cerne de manière à évaluer les effets des facteurs région, placette, arbre et position dans l'arbre sur les composantes densitométriques des arbres. La contribution de chaque effet testé est ensuite estimée par rapport à la variation totale des composantes de la densité. Dans un troisième temps, le modèle mixte de densité moyenne établi à 1,30 m est testé sur un nouvel échantillonnage. Enfin, ce modèle est utilisé pour simuler l'influence de pratiques sylvicoles contrastées sur la densité du bois, la simulation prenant en compte les variabilités inter-arbre pour la densité et la croissance radiale des arbres. (@ Inra/Elsevier, Paris.)

densitométrie / chêne sessile / modèle mixte / simulation

\section{Introduction}

Furniture and joinery, representing the most valuable uses of Oak in France, are known to require solid wood and sliced veneer with low shrinkage, straight grain, less sapwood, fewer knots, light colour and other aesthetic traits such as regular radial growth $[9,16,19]$. The first step towards a better understanding of the

* Correspondence and reprints

guilley@nancy.inra.fr 
determinism of the previously defined wood quality criteria entails the discovery of where the variability of wood properties occurs in a set of standing trees and which factors influence it, either silviculture, environment or genetics. In other words do wood properties vary within trees according to their growth, in which case silviculture and/or environment may be considered to be relevant factors in wood quality determinism and do wood properties vary differently within trees coming from a same stand, in which case genetics may be a significant factor? Many authors studying wood shrinkage $[24,26]$ or analysing spiral grain [2] have partly answered those questions. They have pointed out the variability of wood properties within trees commonly related to tree growth criteria such as age from the pith and ring width which can be partly controlled by forest managers and the large variability between trees in a stand having similar diameter growth. Following the idea that wood quality may be partially influenced by silviculture, another point of interest is to predict with simulation tools whether more intensive silviculture leading to higher volumes of harvested logs in a shorter time would lead to decreased wood quality.

The present paper focuses on wood density, known for long time as a key-criterium of wood quality in Quercus petraea Liebl. For instance wood density is positively associated with mechanical strength and shrinkage $[20,25]$. Because of the large anatomical radial variability within oak rings, the within-ring density components, i.e. earlywood and latewood widths and densities were analysed using X-ray images of 2-mmthick strips. This work was then devoted to the model of variation of within-ring density components in commercial logs in connection with tree growth defined by age from the pith and ring width. First, models of within-tree variation are proposed for wood density components established at breast height in connection with tree growth and according to several factors including region, stand and tree. A more precise interest is then taken in what occurs within trees by analysing the effect of height on density components. The ring average density model established at breast height will be further adjusted on a new sampling method using 16-mm-sized cubes. Finally, the ring average density at breast height will be simulated by statistical tools from intensive silviculture as well as classical silviculture for two sets of trees with the same final diameter but of different ages.

The present study provides new information complementary to the recent work by Zhang et al. [23, 24], Ackermann [1], Degron and Nepveu [4]. This article analyses not only the wood density components according to a wide range of factors (region, stand, tree and position within logs) on the basis of a well-supplied database, namely 24200 scanned rings as well as 3300 16 -mm-sized cubes, but is also innovative in structuring the variability of within-ring density components. In addition, the authors concentrate on their modelling strategy using the procedure PROC MIXED of the SAS Institute [13], which is designed to solve mixed models and which reliably estimates variance components by likelihood estimation [6].

\section{Materials and methods}

\subsection{Tree sampling}

The study was carried out on 82 mature sessile oaks (Quercus petraea Liebl.) with heights ranging from 17 to $40 \mathrm{~m}$, diameters at breast height from 42 to $104 \mathrm{~cm}$, ages at breast height from 61 to 224 years and mean ring widths at breast height from 1.26 to $3.90 \mathrm{~mm}$. The trees were sampled from five regions in France namely Alsace, Allier, Lorraine, Orne-Sarthe and Loir et Cher representing 27 forests and 48 stands. The stands were chosen in order to enlarge ranges of stand conditions and silvicultures. Two even-aged trees with heterogeneous diameters or a single tree were harvested in each stand (34 stands with two trees, 14 stands with a single tree).

\subsection{Measurement methods}

One 20 -cm-thick disc was sawn in each of the 82 harvested oaks at breast height. For 52 oaks out of the 82 trees sample, a second disc between $1.30 \mathrm{~m}$ and the first defect in the commercial log was kept. In other words the breast height level was representative of the whole sample and the mid-level sample only accounted for $\mathbf{5 2}$ trees. The longest radius as well as its diametrically opposite radius were sampled from the sawn discs. In both radii, 2-mm-thick strips were sawn longitudinally, at $12 \%$ of moisture content for X-ray microdensitometric analysis following the procedure described by Polge and Nicholls [21]. The 2-mm-thick strips were exposed for $2 \mathrm{~h}$ to high wave length $\mathrm{X}$-rays, the source of which was at $2.5 \mathrm{~m}$ from a middle grain radiographic film with the following electric characteristics: intensity $10 \mathrm{~mA}$ and accelerating tension $10 \mathrm{kV}$. Previous studies have shown that wood density measured by microdensitometry was slightly different from wood density measured by gravimetry and the ratio between microdensitometric and gravimetric densities, called 'control ratio', varied depending on the samples [14]. Therefore, density components were systematically divided by the control ratio. The next step consisted in automatically measuring the density and ring width of each scanned ring and then cal- 
culating its earlywood and latewood densities according to the earlywood-latewood boundary set on the basis of the following formula [14]:

$$
D_{b}=\beta_{x} D_{\text {tmax }}+\left(1-\beta_{x}\right) D_{\text {tmin }}
$$

where $D_{h}$ is the density at the earlywood-latewood boundary, $\beta_{x}$ is a constant equal to 0.8 for oak wood [15], $\mathrm{D}_{\text {tmax }}$ and $\mathrm{D}_{\mathrm{tmin}}$ are, respectively, the maximum density and the minimum density among the 20 twentieths, $t$, defined within a given ring (each ring is divided into 20 twentieths, one twentieth corresponding to $5 \%$ of the ring width).

\subsection{Modelling strategy with mixed-effect models}

All within-ring density components were studied except latewood width which is equal to the difference between ring width and earlywood width. The sampling structured in terms of radius, height, tree, stand and region allowed us to test whether identical density component models could be applied to both radii and to both heights whatever the trees classified in stands and regions. In other words, does the wood react similarly to an increase in ring width and to maturing whatever its position in the log and whatever the tree?

In the initial analysis, the within-tree variation for density components was analysed in 82 oak trees at breast height and the second analysis concentrated on the effect of ring location on the basis of 52 trees in which two radii at two heights were represented. Consequently the presentation of our results is divided into two main parts: analysis on 82 oak trees at breast height and analysis on height effect on the basis of 52 trees.

\subsubsection{Analysis at breast height}

We modelled the variations of each density components, $y$, with a mixed-effect model as:

$$
y=\beta^{\mathrm{t}} x+v^{\mathrm{t}} z+\varepsilon
$$

where $\beta$ is a fixed-effect vector, $v$ a random-effects vector which follows $\mathrm{N}(0, G), G$ being the variance-covariance matrix of random effects, $x$ is the vector of variables associated with the fixed effects, $z$ is the vector of variables associated with the random effects and $\varepsilon$ is the residual random variation which follows $\mathrm{N}\left(0, \sigma^{2}\right)$. The mixed-effect model allows us to analyse data with several sources of variation and especially within- and between-tree variations. The unknown parameters (fixed-effects, variances of random effects and residual variance) are estimated using restricted maximum likelihood. All analyses were performed using the procedure PROC MIXED available in release 6.09 of SAS/STAT software designed by the SAS Institute [13].

More precisely, the analysis consisted at breast height in testing whether age from the pith and ring width have identical effects depending on the regions, the stands, the trees and the radii. The density component model fitted was then as follows:

$$
\begin{aligned}
Y_{\mathrm{i}(\mathrm{gh}) \mathrm{kl}}=\mathrm{a}+\mathrm{b} x_{\mathrm{i}(\mathrm{gh}) \mathrm{k} l}+\Delta \alpha+\Delta \beta x_{\mathrm{i}(\mathrm{gh}) \mathrm{kl}}+ \\
\\
\delta \mathrm{A}+\delta \mathrm{B} z_{\mathrm{i}(\mathrm{gh}) \mathrm{k}]}+\varepsilon_{\mathrm{i}(\mathrm{gh}) \mathrm{kl}} \quad(2 \mathrm{a}, \mathrm{b}, \mathrm{c}, \mathrm{d})
\end{aligned}
$$

where $g$ denotes the $g$ th region; $h$ the $h$ th stand; i the $i$ th tree; $\mathrm{k}$ the $k$ th radius and 1 the $l$ th ring. $Y$ is a density component, both $x$ and $z$ are vectors with a function of age from the pith and ring width as components. The sub-model ( $2 \mathrm{a})$, made of $\left(\mathrm{a}+\mathrm{b} x_{\mathrm{i}(\mathrm{gh}) \mathrm{kl}}\right)$, is the overall population regression curve, $(2 b)$ are the fixed deviations from (2a), (2c) are the random deviations from (2a), and $(2 \mathrm{~d})$ is the residual variation which follows $\mathrm{N}\left(0, \sigma^{2}\right)$. The sub-model (2b) is equal to $\Delta \alpha+\Delta \beta x_{\mathrm{i}(\mathrm{gh}) \mathrm{kl}}$, where $\Delta \alpha=$ $\Delta \alpha_{g}+\Delta \alpha_{k}+\Delta \alpha_{g k}\left(\Delta \alpha_{g}\right.$, 'Region' effect, $\Delta \alpha_{k}$, 'Radius' effect and $\Delta \alpha_{\mathrm{gk}}$, 'Region $\times$ Radius' interaction) and $\Delta \beta x_{\mathrm{i}(\mathrm{gh}) \mathrm{kl}}=\left(\Delta \beta_{\mathrm{g}}+\Delta \beta_{\mathrm{k}}+\Delta \beta_{\mathrm{gk}}\right) x_{\mathrm{i}(\mathrm{gh}) \mathrm{kl}}$ (i.e. interactions between $x$ and 'Region', 'Radius', 'Region $\times$ Radius', respectively). The sub-model $(2 \mathrm{c})$ is equal to $\delta \mathrm{A}+$ $\delta \mathrm{B} z_{\mathrm{i}(\mathrm{gh}) \mathrm{k})}$, where $\delta \mathrm{A}=\delta \mathrm{A}_{\mathrm{h}}+\mathrm{A}_{\mathrm{i}(\mathrm{h})}+\delta \mathrm{A}_{\mathrm{i(h)k}}\left(\delta \mathrm{A}_{\mathrm{h}}\right.$, 'Stand' effect, $\delta A_{i(h)}$, 'Tree in Stand' effect, $\delta A_{i(h) k}$, 'Radius $x$ Tree in Stand' interaction) and $\delta \mathrm{B} z_{\mathrm{i}(\mathrm{gh}) \mathrm{kl}}=\left(\delta \mathrm{B}_{\mathrm{h}}+\delta \mathrm{B}_{\mathrm{i}(\mathrm{h})}+\right.$ $\left.\delta \mathrm{B}_{\mathrm{i}(\mathrm{h}) \mathrm{k}}\right) z_{\mathrm{igh}) \mathrm{kl}}$ (i.e. interactions between $z$ and 'Stand', 'Tree in Stand', 'Radius $x$ Tree in Stand', respectively). The random effect vector made $\delta \mathrm{A}$ and $\delta \mathrm{B}$ follows $\mathrm{N}(0$, $G), G$ being the variance-covariance matrix of random effects. In model (2), $G$ is a diagonal matrix where the covariances are forced to zero.

\subsubsection{Analysis of height effect on the basis of 52 oaks}

This analysis refers to the following model with the same suffixes as above:

$$
\begin{aligned}
Y_{\mathrm{ijkl}}=\mathrm{a}^{\prime}+\mathrm{b}^{\prime} x_{\mathrm{ijk1}}+\Delta \alpha^{\prime}+\Delta \beta^{\prime} x_{\mathrm{ijkl}} \\
+\delta \mathrm{A}^{\prime}+\delta \mathrm{B}^{\prime} z_{\mathrm{ijkl}}+\varepsilon_{\mathrm{ijkl}}^{\prime} \quad(3 \mathrm{a}, \mathrm{b}, \mathrm{c}, \mathrm{d})
\end{aligned}
$$

where $\mathrm{i}$ denotes the $i$ th tree; $\mathrm{j}$ the $j$ th height, $\mathrm{k}$ the $k$ th radius and 1 the $l$ th ring. $Y$ is a density component, both $x$ and $z$ are vectors with a function of age from the pith and ring width as components. The sub-model ( $3 a)$, made of $\left(a^{\prime}+b^{\prime} x_{i, k l}\right)$, is the overall population regression curve, $(3 b)$ are the fixed deviations from (3a), (3c) are the random deviations from (3a), and ( $3 \mathrm{~d})$ is the residual variation which follows $\mathrm{N}\left(0, \sigma^{\prime 2}\right)$. The sub-model $(3 \mathrm{~b})$ is equal to $\Delta \alpha^{\prime}+\Delta \beta^{\prime} x_{\mathrm{ijk}}$, where $\Delta \alpha^{\prime}=\Delta \alpha_{j}^{\prime}+\Delta \alpha_{\mathrm{k}}^{\prime}+\Delta \alpha_{\mathrm{jk}}^{\prime}$ $\left(\Delta \alpha_{j}^{\prime}\right.$, 'Height' effect, $\Delta \alpha_{k}^{\prime}$, 'Radius' effect and $\Delta \alpha_{j \mathrm{j}}^{\prime}$ ' 'Height $\times$ Radius' interaction $)$ and $\Delta \beta^{\prime} x_{\mathrm{ijk} l}=\left(\Delta \beta_{\mathrm{j}}^{\prime}+\Delta \beta_{\mathrm{k}}^{\prime}\right.$ 
$\left.+\Delta \beta_{j k}^{\prime}\right) x_{i j k l}$ (i.e. interactions between $x$ and 'Height', 'Radius ', 'Height $\times$ Radius', respectively). The submodel (3c) is equal to $\delta \mathrm{A}^{\prime}+\delta \mathrm{B}^{\prime} z_{\mathrm{ijk}}$, where $\delta \mathrm{A}^{\prime}=\delta \mathrm{A}_{\mathrm{i}}^{\prime}+$ $\delta \mathrm{A}_{\mathrm{ij}}^{\prime}+\delta \mathrm{A}_{\mathrm{ik}}^{\prime}+\delta \mathrm{A}_{\mathrm{ijk}}^{\prime}\left(\delta \mathrm{A}^{\prime}{ }_{\mathrm{i}}\right.$, 'Tree' effect, $\delta \mathrm{A}_{\mathrm{ij}}^{\prime}$, 'Tree $\times$ Height' interaction, $\delta A^{\prime}{ }^{\prime}$, 'Tree $\times$ Radius' interaction, $\delta \mathrm{A}^{\prime}{ }_{\mathrm{ijk}}$ 'Tree $\times$ Height $\times$ Radius' interaction) and $\delta \mathrm{B}^{\prime} z_{\mathrm{ijkl}}=$ $\left(\delta \mathrm{B}_{\mathrm{i}}^{\prime}+\delta \mathrm{B}_{\mathrm{ij}}^{\prime}+\delta \mathrm{B}_{\mathrm{ik}}^{\prime}+\delta \mathrm{B}_{\mathrm{ijk}}^{\prime}\right) z_{\mathrm{ijk}}$ (i.e. interactions between $z$ and 'Tree', 'Tree $\times$ Height', 'Tree $\times$ Radius', 'Tree $\times$ Height $\times$ Radius', respectively). The random effect vector made of $\delta \mathrm{A}^{\prime}$ and $\delta \mathrm{B}^{\prime}$ follows $\mathrm{N}\left(0, G^{\prime}\right), G^{\prime}$ being the variance-covariance matrix of random effects. In model (3), $G^{\prime}$ is a diagonal matrix where the covariances are forced to zero.

The contribution of each tested factor was then evaluated by splitting the total variability of density components into a variation explained by fixed effects, variations due to random effects and into a residual variance according to Hervé's calculations [8].

\subsection{Microdensity model applicable to gravimetric density?}

Could the ring average density model, established at ring level, be applied at group of rings level? To answer this question, the ring average density model (2), established at breast height at ring level, was applied to samples from the new sampling method using 16-mm-sized cubes. The cubes, at $12 \%$ air-dry conditions, were sampled from the previously mentioned 82 oaks and sawn into two radii just above the ones used for microdensitometric analyses. The mean age from the pith, the mean ring width as well as the density given by the ratio between weight and volume were known for each cube.

\subsection{Influence of silviculture on wood density}

The influence of silviculture on wood density was simulated on the basis of i) the ring average density model (2) and ii) two ring width profiles. The latter profiles represent two different types of silviculture, a traditional one with a relatively slow growth rate $(1.71 \mathrm{~mm}$ in mean ring width) referred to as 'classical silviculture' and an intensive one leading to accelerated tree growth (2.53 $\mathrm{mm}$ in mean ring width), referred to as 'dynamic silviculture'. These two types of silviculture were simulated by Dhôte [5] for an average-to-good quality stand (top height at 100 years equal to $26 \mathrm{~m}$ ). The classical scenario led on average to trees of $64 \mathrm{~cm}$ in diameter at breast height after 200 years and the dynamic one to trees with a breast height diameter of $60 \mathrm{~cm}$ after 124 years. In classical silviculture a final crop of 100 trees was produced which exhibited large variations in breast height diameter $(44 \mathrm{~cm}$ for the smallest tree and $83 \mathrm{~cm}$ for the largest one), whereas the 93 trees in the final crop produced by dynamic silviculture exhibited smaller differences in breast height diameter between the smallest and the largest tree $(57$ and $64 \mathrm{~cm}$, respectively).

\section{Results and discussion}

\subsection{Analysis at breast height on 82 oak trees}

\subsubsection{Fixed effects}

The column entitled 'Mean' in table I represents the overall population regression curves. For earlywood width (EW), earlywood density (ED), latewood density (LD) and ring average density (AD), the population curves are, respectively:

$$
\begin{aligned}
& \mathrm{EW}=0.677+0.225 \mathrm{P} 2 \\
& \mathrm{ED}=565-126 \mathrm{P} 1+24 \mathrm{P} 2 \\
& \mathrm{LD}=796-157 \mathrm{P} 1+20 \mathrm{P} 2 \\
& \mathrm{AD}=706-159 \mathrm{P} 1+46 \mathrm{P} 2
\end{aligned}
$$

where $\mathrm{P} 1$ and $\mathrm{P} 2$ are centred variables, age from the pith minus 0.8 (hundreds of years) and ring width minus 1.8 $(\mathrm{mm})$, respectively. The models (4)-(7) show that, on average, earlywood and latewood density as well as ring average density decrease with increasing age from the pith and increase with ring width, while earlywood width increases with ring width without being influenced by age from the pith. These results are partly confirmed by Zhang et al. [23] on Quercus petraea and Quercus robur, Ackermann [1] on Quercus robur and Degron and Nepveu [4] on Quercus petraea. Nevertheless Degron and Nepveu [4] considered earlywood width to be constant from the pith to the bark. Thus, according to these authors, ring width did not influence earlywood width. This result can be explained by the low variability of ring width in their sample. Eyono Owoundi [7] and Ackerman [1] found a significant correlation between earlywood width and ring width $\left(\mathrm{R}^{2}=0.65\right.$ and $\mathrm{R}^{2}=0.57$, respectively) which corroborates our results. Table $I$ is also eloquent in relating that on average the regions present hardly any dissimilarities in terms of density components so far as trees with identical radial growth are concerned. On the contrary, the ring location, either in the longest radius, either in the diametrically opposed radius, systematically influences wood density (when significant 'Radius' effect, refer to estimated fixed-effect parameters for the longest radius and its diametrically opposed radius in table $I$ ). In order to identify the precise contribution of the fixed effects, the total variation of density components was split, as shown in 
Table I. Estimated fixed-effect parameters with statistical significance and estimated random-effect variances with statistical significance and precision of estimation (in brackets) for earlywood width, earlywood density, latewood density and ring average density.

\begin{tabular}{|c|c|c|c|c|c|c|c|c|}
\hline \multirow[t]{2}{*}{ Density components } & & \multicolumn{4}{|c|}{ Fixed effects } & \multicolumn{3}{|c|}{ Random effects } \\
\hline & & Mean & Region & Radius & Region $\times$ Radius & Stand & Tree (Stand) & Tree $($ Stand $) \times$ Radius \\
\hline \multirow{3}{*}{$\begin{array}{l}\text { Earlywood } \\
\text { width }(\mathrm{mm})\end{array}$} & INT & 0.677 & * & * & NS & - & $* * *$ & $* * *$ \\
\hline & P2 & 0.225 & $\begin{array}{c}0.631 \text { to } 0.704 \\
* *\end{array}$ & $0.684 \underset{*}{a} 0.670$ & NS & _- & $\underset{* *}{0.0040(0.0007)}$ & $\begin{array}{c}0.0008(0.0002) \\
* * *\end{array}$ \\
\hline & & & 0.194 to 0.257 & 0.217 and 0.233 & & & $0.0011(0.0004)$ & $0.0017(0.0004)$ \\
\hline \multirow{4}{*}{$\begin{array}{l}\text { Earlywood density } \\
\left(\mathrm{kg} / \mathrm{m}^{3}\right)\end{array}$} & INT & 565 & NS & NS & NS & NS & ** & $* * *$ \\
\hline & P1 & -126 & NS & $* * *$ & NS & * & $\begin{array}{c}1000(3 / 5) \\
\text { NS }\end{array}$ & $\begin{array}{c}041(112) \\
* * *\end{array}$ \\
\hline & P2 & 24 & NS & -114 and -140 & NS & $\begin{array}{c}1236(579) \\
\text { NS }\end{array}$ & NS & $1748(329)$ \\
\hline & & & & 22 and 26 & & & & $119(33)$ \\
\hline \multirow{4}{*}{$\begin{array}{l}\text { Latewood density } \\
\left(\mathrm{kg} / \mathrm{m}^{3}\right)\end{array}$} & INT & 796 & NS & NS & NS & NS & *** & $* * *$ \\
\hline & P1 & -157 & NS & $* * *$ & NS & $*$ & $\begin{array}{c}1870(583) \\
\text { NS }\end{array}$ & $\begin{array}{c}698(121) \\
* * *\end{array}$ \\
\hline & & & & -141 and -173 & & $1921(774)$ & & $1607(317)$ \\
\hline & $\mathrm{P} 2$ & 20 & NS & 15 and 26 & NS & NS & NS & $138(35)$ \\
\hline \multirow{4}{*}{$\begin{array}{l}\text { Ring average density } \\
\left(\mathrm{kg} / \mathrm{m}^{3}\right)\end{array}$} & INT & 706 & NS & NS & NS & NS & ** & $* * * *$ \\
\hline & P1 & -159 & NS & $* * *$ & NS & $* *$ & $\begin{array}{c}\text { NS } \\
\text { NS }\end{array}$ & $\begin{array}{c}031(110) \\
* * * *\end{array}$ \\
\hline & $\mathrm{P} 2$ & 46 & NS & -143 and -175 & NS & $\begin{array}{c}1820(665) \\
*\end{array}$ & NS & $\begin{array}{c}1583(302) \\
* * *\end{array}$ \\
\hline & & & & 39 and 53 & & $232(93)$ & & $173(39)$ \\
\hline
\end{tabular}

' $\mathrm{P} 1$ ' and ' $\mathrm{P} 2$ ' correspond to centred quantitative variables, age from the pith minus 0.8 (hundreds of years) and ring width minus 1.8 (mm), respectively.

The interactions between quantitative effects and qualitative effects, for instance $\mathrm{P} 2 \times$ Tree(Stand), are presented at the intersection between the lines entitled 'PI' or 'P2' and the columns entitled 'fixed effects' or 'random effects', the qualitative effects are presented at the intersection between the line entitled 'INT' and the columns entitled 'fixed effects' or 'random effects', in column entitled 'Mean' are the population regression parameters.

The sign '-' means that the effect in corresponding cell has not been tested.

table $I I$, into a) a variation explained by fixed effects, b) variances due to random effects and c) a residual variance. As a result of splitting, the fixed effects explain $53.3,26.9,34.4$ and $37.7 \%$ of the total variation for earlywood width, earlywood density, latewood density and ring average density, respectively.

\subsubsection{Random effects}

\subsubsection{Variability of wood density components according to stands}

Table II reports the results of the analysis based on model (2) testing where the variability of density components occurs, either between trees in a stand or between stands. The variability between trees in a stand represents $24.4,26.1$ and $22.8 \%$ (sum of the six components in columns entitled 'Tree' and 'Tree(Stand) $\times$ Radius'), whereas the variability between stands represents 6.5 , 9.9 and $12.4 \%$ (sum of the three components in column entitled 'Stand') for earlywood density, latewood density and ring average density, respectively. These results agree with Ackermann [1] who found that in Quercus robur the factor 'tree nested in stand' explained most of the observed variability when age from the pith and ring width were fixed.

\subsubsection{Between trees variability}

The 'Tree(Stand)' effect is significant for all density components as indicated in table I where the estimated random-effect variances are given with their precision of estimation. These results are in accordance with the conclusions drawn by Zhang et al. [23] and confirmed by Degron and Nepveu [4] who pointed out the individual variability in Quercus petraea Liebl. and Quercus robur L. In model (2), the so-called 'Tree(Stand)' effect includes three components: first, the specific behaviour of the trees to maturing, i.e. 'Tree $($ Stand) $\times \mathrm{P} 1$ ' interaction; second, the specific behaviour of the trees to an 
Table II. Contribution of fixed effects and random effects on total variation of earlywood width, earlywood density, latewood density and ring average density.

\begin{tabular}{|c|c|c|c|c|c|c|c|}
\hline \multirow{2}{*}{$\begin{array}{l}\text { Density } \\
\text { components }\end{array}$} & \multirow{2}{*}{$\begin{array}{c}\text { Total } \\
\text { variation }\end{array}$} & \multirow{2}{*}{$\begin{array}{l}\text { Variation explained } \\
\text { by fixed effects }\end{array}$} & & \multicolumn{3}{|c|}{ Variance due to random effects } & \multirow{2}{*}{$\begin{array}{l}\text { Residual } \\
\text { variance }\end{array}$} \\
\hline & & & & Stand & Tree (Stand) & Tree $($ Stand $) \times$ Radius & \\
\hline $\begin{array}{l}\text { Earlywood } \\
\text { width (mm) }\end{array}$ & $100 \%$ & $53.3 \%$ & $\begin{array}{l}\text { INT } \\
\text { P2 }\end{array}$ & $\begin{array}{l}- \\
-\end{array}$ & $\begin{array}{l}3.9 \% \\
0.9 \%\end{array}$ & $\begin{array}{l}0.8 \% \\
1.5 \%\end{array}$ & $39.7 \%$ \\
\hline $\begin{array}{l}\text { Earlywood } \\
\text { density } \\
\left(\mathrm{kg} / \mathrm{m}^{3}\right)\end{array}$ & $100 \%$ & $26.9 \%$ & $\begin{array}{l}\text { INT } \\
\text { P1 } \\
\text { P2 }\end{array}$ & $\begin{array}{l}3.1 \% \\
2.9 \% \\
0.5 \%\end{array}$ & $\begin{array}{l}11.3 \% \\
1.2 \% \\
0.5 \%\end{array}$ & $\begin{array}{l}6.3 \% \\
4.1 \% \\
1.0 \%\end{array}$ & $42.2 \%$ \\
\hline $\begin{array}{l}\text { Latewood } \\
\text { density } \\
\left(\mathrm{kg} / \mathrm{m}^{3}\right)\end{array}$ & $100 \%$ & $34.4 \%$ & $\begin{array}{l}\text { INT } \\
\mathrm{P} 1 \\
\mathrm{P} 2\end{array}$ & $\begin{array}{l}5.7 \% \\
3.5 \% \\
0.7 \%\end{array}$ & $\begin{array}{l}14.4 \% \\
1.8 \% \\
0.7 \%\end{array}$ & $\begin{array}{l}5.4 \% \\
2.9 \% \\
0.9 \%\end{array}$ & $29.5 \%$ \\
\hline $\begin{array}{l}\text { Ring average } \\
\text { density } \\
\left(\mathrm{kg} / \mathrm{m}^{3}\right)\end{array}$ & $100 \%$ & $37.7 \%$ & $\begin{array}{l}\text { INT } \\
\text { P1 } \\
\text { P2 }\end{array}$ & $\begin{array}{l}7.2 \% \\
3.5 \% \\
1.7 \%\end{array}$ & $\begin{array}{l}11.4 \% \\
0.9 \% \\
0.9 \%\end{array}$ & $\begin{array}{l}5.2 \% \\
3.1 \% \\
1.3 \%\end{array}$ & $27.1 \%$ \\
\hline
\end{tabular}

'P1' and 'P2' correspond to centred quantitative variables, age from the pith minus 0.8 (hundreds of years) and ring width minus 1.8 (mm), respectively.

The interactions between quantitative effects and qualitative effects, for instance P2 $\times$ Tree(Stand), are presented at the intersection between the lines entitled 'Pl' or 'P2' and the columns entitled 'Variance due to random effects', the qualitative effects are presented at the intersection between the line entitled 'INT' and the columns entitled 'Variance due to random effects'.

The sign '-' means that the effect in corresponding cell has not been tested.

increase in ring width, i.e. 'Tree(Stand) $\times$ P2' interaction, both meaning, when significant, that trees with similar radial growth could behave differently in term of wood density with increasing age from the pith and ring width. The third component is the intrinsic nature of the trees, i.e. 'Tree(Stand)' factor which means that trees might have different density even near the pith. Polge and Keller [20] observed earlier that trees do not exhibit similar density with ring width and stated that it was always possible to find oaks with large rings and rather low wood specific gravity. However, in our sampling, the 'Tree $($ Stand $) \times \mathrm{P} 1$ ' and 'Tree(Stand) $\times$ P2' interactions are not found to be significant. This result suggests that trees with similar radial growth may exhibit almost parallel within-ring density profiles, which is equivalent to saying that trees exhibiting different density components between each other at young stages may preserve this dissimilarity of density components for their whole life.

\subsubsection{Variability around the girth}

Table I also exhibits a highly significant 'Tree(Stand) $\times$ Radius' interaction. This result indicates that the effect of ring location does not have the same intensity according to trees. The presence of tension wood in some trees could explain this phenomenon. Unfortunately this hypothesis associating tension wood with disturbances in wood density has not been verified in our sampling. It is even more difficult to verify this hypothesis because neither the degree of inclination nor the eccentricity of stems allow one to draw conclusions about the content of tension wood $[18,22]$, as microscopic examination of thin sections of wood or differential coloration are the only reliable indicators of tension wood [18]. Until now, no study on Oak has been carried out to compare tension wood and normal wood as regards their specific densities. However, tension wood density of other hardwoods such as Poplar and Beech has been widely studied and this gives substance to the relation in Oak between irregularities of wood density and presence of tension wood. For instance, in Populus, the presence of tension wood is evaluated by higher density zones $[3,17]$ and tension wood within a given tree is from 18 to $27 \%$ denser (oven-dry density) than normal wood [12]. In Fagus silvatica, tension wood is also characterised by higher density [10]. Nevertheless as shown by table $I I$, the 'Tree(Stand) $\times$ Radius' variability is inferior to the 'Tree' variability (refer to line 'INT'). Indeed the variance due to the 'Tree(Stand)' factor represents 3.9, 11.3, 14.4 and $11.4 \%$ while the variance due to 'Tree(Stand) $\times$ Radius' interaction counts for 0.8, 6.3, 5.4 and $5.2 \%$, respectively, for earlywood width, earlywood density, latewood density and ring average density. The resemblance, i.e. the correlation between two radii of a given 
tree, which is set on the basis of the following formula $\rho_{\text {radius }}=\left(\right.$ Variance $_{\text {stand }}+$ Variance $\left._{\text {tree }}\right) /\left(\right.$ Variance $_{\text {stand }}+$ Variance $_{\text {tree }}+$ Variance $\left._{\text {tree } x \text { radius }}\right)$, varies from 0.68 and 0.83 according to the density components taken into account.

\subsection{Analysis of height effect on the basis of 52 oaks}

The analysis based on model (3) reveals a systematic effect of height on density components (fixed 'Height' effect) as well as a strong interaction 'Tree $\times$ Height $\times$ Radius' which is as significant as the 'Tree' effect, as table III emphasises clearly. According to the variance decomposition set in table $I V$, the interaction Tree $\times$ Height $\times$ Radius' represents $1.2,6.1$ and $5.7 \%$, whereas the 'Tree' factor participates in $3.8,12.6$ and $9.8 \%$ of the whole variance for earlywood width, latewood density and ring average density, respectively. Further work based on many more heights within trees is necessary to explain the latter behaviour.

\subsection{Microdensity model applicable to gravimetric density}

As illustrated in figure 1 , the densities measured on 16-mm-sized cubes are compared with the densities estimated from the ring average density model (2) established at ring level. The estimated densities are intimately related to the measured densities in terms of mean (715 and $716 \mathrm{~kg} \mathrm{~m}^{-3}$, respectively) and variance (7 294 and $7038\left(\mathrm{~kg} \mathrm{~m}^{-3}\right)^{2}$, respectively).

Table III. Estimated fixed-effect parameters with statistical significance and estimated random-effects variances with statistical significance and precision of estimation (in brackets) for earlywood width, earlywood density, latewood density and ring average density.

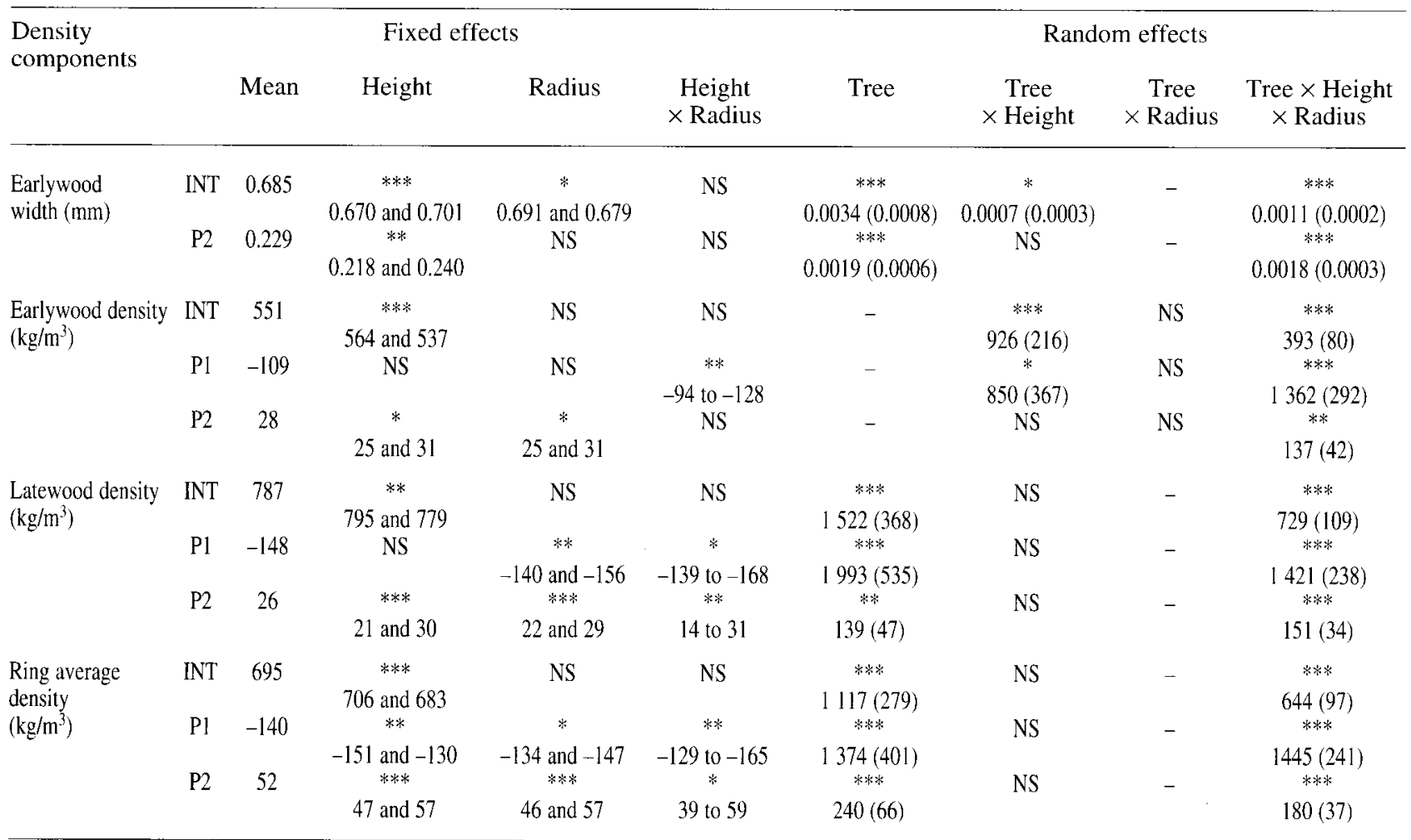

'Pl' and 'P2' correspond to centred quantitative variables, age from the pith minus 0.8 (hundreds of years) and ring width minus 1.8 (mm), respectively.

The interactions between quantitative effects and qualitative effects, for instance P $2 \times$ Tree, are presented at the intersection between the lines entitled 'P1' or 'P2' and the columns entitled 'fixed effects' or 'random effects', the qualitative effects are presented at the intersection between the line entitled 'INT' and the columns entitled 'fixed effects' or 'random effects', in column entitled 'Mean' are the population regression parameters.

The sign '-' means that the effect in corresponding cell has not been tested. 


\subsection{Simulation of contrasting silvicultural influences}

The two types of silvicultural regime inevitably influence the radial pattern of wood density as illustrated in figure 2. The same 11 trees, in which the densest tree and the least dense tree are chosen from the final crop in classical and dynamic silviculture, present their own ring average density variation from the pith to the bark. Since ring average density decreases with increasing age from the pith, the trees in classical silviculture have lower density at the same radial position than in the dynamic scenario just because they are older and thus present more heterogeneous densities in so far as their radial evolution in density is concerned. Conversely, the heavy thinning during dynamic silviculture is reflected in ring average density profiles which exhibit higher local heterogeneities than the ones produced with slow growth rate. With reference to generally held opinions, local heterogeneities in density are prejudicial to sliced veneer quality and will probably imply worse machinability and higher deformations during drying. However, the authors qualify that remark since the heterogeneities in ring width induced by climate which are probably much higher than the ones induced by thinnings are not simulated. The dynamic silviculture gives encouraging results if it is applied over 200 years as for the classical silviculture. Indeed, at overall population level, for a same rotation age, the increase in density from dynamic to classical sil-

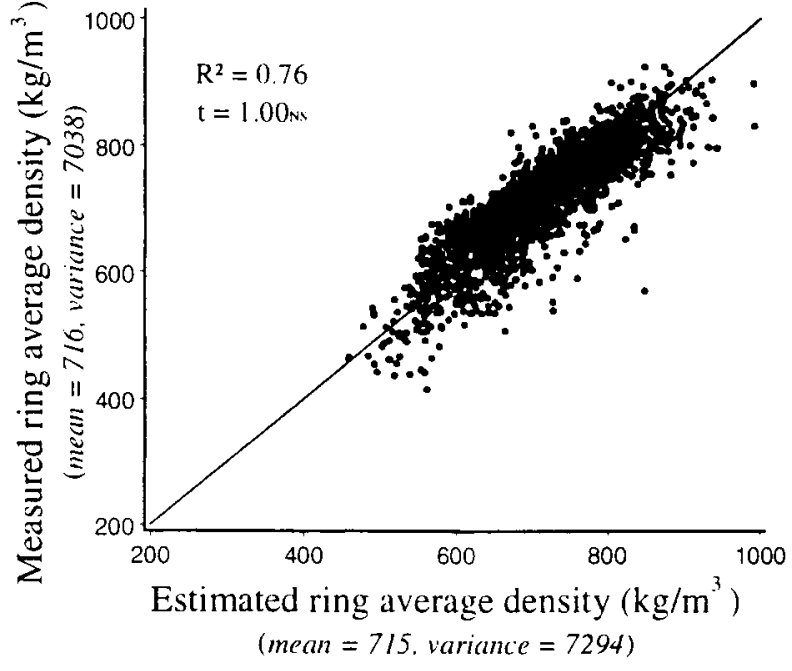

Figure 1. Comparison between the densities measured on 16mm-sized cubes and the densities estimated from the ring average density model (2) established at ring level.

vicultures is only $37.7 \mathrm{~kg} \mathrm{~m}^{-3}$ (refer to the population regression: Density dynamic - Density $_{\text {classic }}=46 \times(2.53-$ $1.71)=37.7 \mathrm{~kg} \mathrm{~m}^{-3}, 2.53$ and 1.71 being the mean ring

Table IV. Contribution of fixed effects and random effects on total variation of earlywood width, earlywood density, latewood density and ring average density.

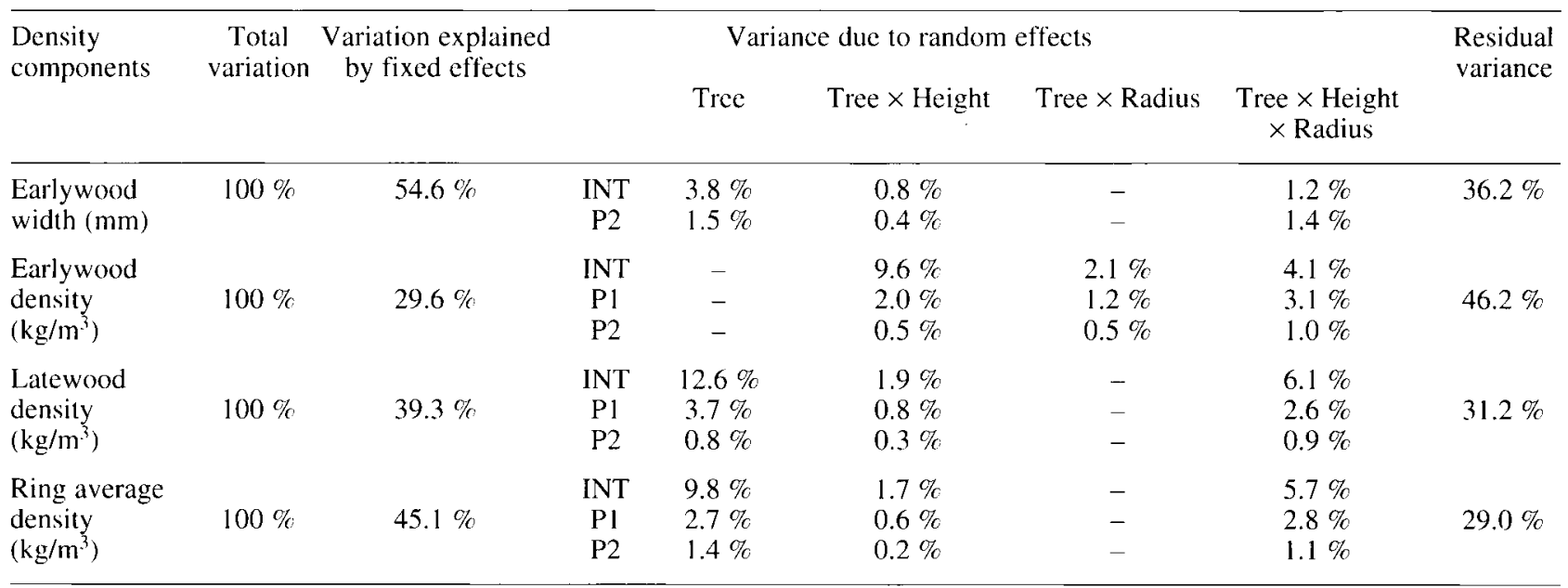

'P1' and 'P2' correspond to centred quantitative variables, age from the pith minus 0.8 (hundreds of years) and ring width minus 1.8 $(\mathrm{mm})$, respectively.

The interactions between quantitative effects and qualitative effects, for instance $\mathrm{P} 2 \times$ Tree, are presented at the intersection between the lines entitled 'P1' or 'P2' and the columns entitled 'Variance due to random effects', the qualitative effects are presented at the intersection between the line entitled 'INT' and the columns entitled 'Variance due to random effects'.

The sign '-' means that the effect in corresponding cell has not been tested. 

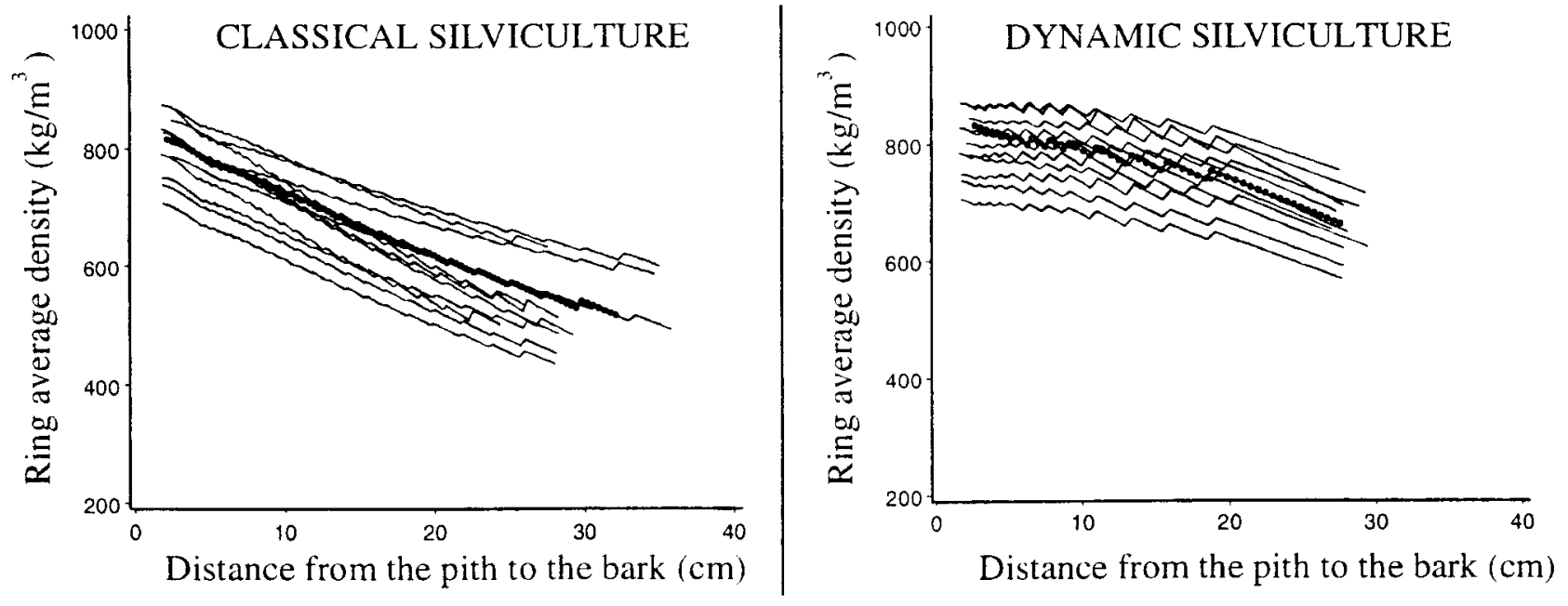

Figure 2. Influence of contrasting silvicultures on wood density.

The scenario termed as classical silviculture leads to trees $64 \mathrm{~cm}$ in diameter at breast height after 200 years $(44 \mathrm{~cm}$ for the thinnest and $83 \mathrm{~cm}$ for the largest tree) and the scenario termed as dynamic silviculture leads to trees $60 \mathrm{~cm}$ in diameter at breast height after 124 years $(57 \mathrm{~cm}$ for the thinnest and $64 \mathrm{~cm}$ for the largest tree); each thin line profile represents the ring average density variation from the pith to the bark for the same 11 trees chosen among the 100 and 93 trees in the final crop, respectively, for the classical and the dynamic silviculture (the densest tree and the least dense tree are present) and the bold dot profile represents the overall population regression.

width for the dynamic and classical silvicultures, respectively).

The dynamic silviculture, where almost every tree grows similarly in diameter, perfectly illustrates the between-tree variability. Indeed the trees exhibit almost parallel density profiles meaning that trees differ intrinsically from each other and react quite similarly with increasing age from the pith and ring width.

\section{Conclusion and perspectives}

In a large sample of 82 oaks, the analyses of the effects of various factors such as region, stand, tree and position within commercial logs, on wood density components complete the conclusions of previous studies by Nepveu [16], Zhang et al. [23, 24], Ackermann [1], Degron and Nepveu [4] who shed light on wood density variability. In the present study within-ring density in Oak is found to increase with ring width and to decrease with increasing age from the pith. At breast height, the fixed effects explain 53.3, 26.9, 34.4 and $37.7 \%$ of the total variation for earlywood width, earlywood density, latewood density and ring average density, respectively. The regions present on average hardly any dissimilarities in terms of density components so far as trees with identical radial growth are concerned while the ring location along the girth systematically influences wood density, meaning that wood on either side of the pith behaves differently to maturing and to an increase in ring width. As regards the random effects, the variability between trees in stand represents $24.4,26.1$ and $22.8 \%$, whereas the variability between stands represents $6.5,9.9$ and $12.4 \%$ for earlywood density, latewood density and ring average density, respectively. Trees with similar radial growth exhibit almost parallel within-ring density profiles, meaning that trees differ intrinsically from each other and react quite similarly with increasing age from the pith and ring width. What occurs within the logs, namely around the girth using two diametrically opposed radii, is also demonstrated. The effect of ring location has not the same intensity according to trees, one hypothesis put forward is the presence of tension wood in the trees for which this behaviour is observed. The analysis based on 52 oaks at two heights reveals a systematic effect of height on density components as well as a strong interaction 'Tree $\times$ Height $\times$ Radius' which is as significant as the 'Tree' effect.

The ring average density model solved by the PROC MIXED procedure allows one to simulate the effects of two contrasting silvicultures by taking into account the variability between trees in a stand. The dynamic silviculture induces local heterogeneities in ring average density. On the other hand, in its favour, a more intensive 
silviculture, leading to higher volumes of harvested logs for the same rotation age than classical silviculture, leads to a low increase in wood density compared to that occurring in classical silviculture.

Acknowledgements: This study was supported by a Research Convention 1992-1996 linking the Office national des forêts and the Institut national de la recherche agronomique entitled 'Silviculture and wood quality in Quercus petraea Liebl.' and by UE-FAIR project 1996-1999 OAK-KEY CT950823 'New silvicultural alternatives in young oak high forests. Consequences on high quality timber production' coordinated by Dr Francis Colin. This study was carried out with technical collaboration of Simone Garros and Thérèse Hurpeau as well as Pierre Gelhaye.

\section{References}

[1] Ackermann F., Influence du type de station forestière sur les composantes intracernes de la densité du bois du chêne pédonculé (Quercus robur L.) dans les chênaies de l'Adour et des côteaux basco-béarnais, Ann. Sci. For. 52 (1995) 635-652.

[2] Aebischer D.P., Denne M.P., Spiral grain in relation with cambial age and ring width in European oak (Quercus petraea Matt (Liebl.) and Quercus robur L.), Holzforschung 50(4) (1996) 297-302.

[3] Castéra P., Nepveu G., Mahé F., Valentin G., A study on growth stresses, tension wood distribution and other related wood defects in poplar (Populus euramericana cv I214): end splits, specific gravity and pulp yield, Ann. Sci. For. 51 (1994) 301-313.

[4] Degron R., Nepveu G., Prévision de la variabilité intraet interarbre de la densité du bois de Chêne rouvre (Quercus petraea Liebl.) par modélisation des largeurs et des densités des bois initial et final en fonction de l'âge cambial, de la largeur de cerne et du niveau dans l'arbre, Ann. Sci. For. 53 (1996) 1019-1030.

[5] Dhôte J.F., Construction d'un modèle arbre, in: Rapport d'avancement de la Convention ONF-INRA 1992-1996, Sylviculture et Qualité du Bois de Chêne (Chêne rouvre), Document interne à l'Equipe de Recherches de la Qualité du Bois, Inra Nancy, 1995, pp. 34-49.

[6] Diggle P.J., Liang K.Y., Zeger S.L. Analysis of Longitudinal Data, Oxford University Press, Oxford, 1994.

[7] Eyono Owoundi R., Modélisation de la rétractibilité du bois en relation avec des paramètres de la structure de l'accroissement annuel et de la position dans l'arbre chez Quercus robur L. et Quercus petraea Liebl. Application à l'intégration de la rétractabilité du bois dans les modèles de croissance de peuplements et d'arbres, Thèse de docteur en sciences du bois, ENGREF Nancy, 1992, 233 p.

[8] Hervé J.C., Décomposition de la variation dans un modèle linéaire mixte, in-house note, 1996.
[9] Janin G., Mazet J.F., Flot J.L., Hofmann P., Couleur et qualité du bois du chêne de tranchage: chêne sessile, chêne pédonculé et chêne rouge, Rev. For. Fr. 2 (1990) 134-139.

[10] Janin G., Ory J.M., Bucur V., Les fibres de bois de réaction, A.T.I.P. 44 (1990) 268-275.

[11] Laird N.M., Ware J.H., Random-effects models for longitudinal data, Biometrics 38 (1982) 963-974.

[12] Lenz O., Le bois de quelques peupliers de culture en Suisse, Ann. Inst. féd. rech. for. 30 (1954) 9-58.

[13] Littell R.C., Milliken G.A., Stroup W.W., Wolfinger R.D., SAS System for Mixed Models, SAS Institute Inc., Cary, 1996.

[14] Mothe F., Duchanois G., Zannier B., Leban J.M., Analyse microdensitométrique appliquée au bois: une méthode de traitement des données aboutissant à la description synthétique et homogène des profils de cernes (programme CERD), Ann. Sci. For. 55 (1998) 301-315.

[15] Mothe F., Sciama D., Leban J.M., Nepveu G., Localisation de la transition bois initial - bois final dans un cerne de Chêne par analyse microdensitométrique, Ann. Sci. For. 55 (1998) 437-449.

[16] Nepveu G., Les facteurs influençant la qualité du bois de chêne (chêne rouvre et chêne pédonculé), Rev. For. Fr, 42 (1990) 128-133.

[17] Nepveu G., Puissan C.M., Garros S., Boury S., Senac J., Le peuplier en bois d'oeuvre: problèmes de qualité; déterminismes génétique, sylvicole et environnemental des propriétés et aptitudes technologiques. Une tentative de synthèse des travaux de recherche publiés ou en cours, C. R. Acad. Agric. Fr. 81 (1995) 225-242.

[18] Panshin A.J., de Zeeuw C., Textbook of Wood Technology, McGraw-Hill, New York, 1981.

[19] Polge H., Chênes de marine et chênes de tranchage, Rev. For. Fr. 4 (1990) 455-461.

[20] Polge H., Keller R., Qualité du bois et largeur d'accroissements en forêt de Tronçais, Ann. Sci. For. 30 (1973) 91-125.

[21] Polge H., Nicholls J.W.P., Quantitative radiography and the densitometric analysis, Wood. Sci. 5 (1972) 51-59.

[22] Sachsse V.H., Portion and distribution of tension wood in Beech stemwood, Holz als Roh. 19 (1961) 253-259.

[23] Zhang S.Y., Eyono Owoundi R., Nepveu G., Mothe F., Dhôte J.F., Modelling wood density in European oak (Quercus petraea and Quercus robur) and simulating the silvicultural influence, Can. J. For. Res. 23 (1993) 2587-2593.

[24] Zhang S.Y., Nepveu G., Eyono Owoundi R., Intratree and intertree variation in selected wood quality characteristics of European oak (Quercus robur L. and Quercus petraea Liebl.), Can. J. For. Res. 24 (1994) 1818-1823.

[25] Zhang S.Y., Nepveu G., Mothe F., Modelling intratree wood shrinkage in European oak by measuring wood density, For. Prod. J. 44 ( 1994) 42-46.

[26] Zhang S.Y., Eyono Owoundi R., Nepveu G., Mothe F., Modelling wood shrinkage and simulating the silvicultural influence in European Oak (Quercus petraea and Quercus robur), Holzforschung 49 (1995) 35-44. 